\title{
KONSEP DASAR PENGEMBANGAN KURIKULUM PENDIDIKAN AGAMA ISLAM DI SEKOLAH
}

\author{
Rahmad Nauli Siregar \\ Kementerian Anama Renı ıblik Indnnecia Kahınaten Tananıli Selatan \\ J. Kenanca No 72 I liınn Padano Padancsidimnı ıan Selatan \\ Kota Padangsidimpuan, Sumatera Utara 22725 \\ E-mail: rahmadnaulisgr@yahoo.co.id
}

\begin{abstract}
Abstrak
Dasar Kurikulum pendidikan Islam adalah Al-Qur'an dan Hadist, akan tetapi tidak dijelaskan secara terperinci. Dalam Al-Qur'an dan Hadist Istilah kurikulum lebih di arahkan pada pokok-pokok materi yang akan diajarkan pada peserta didik. Orientasi kurikulum PAI mengacu pada pengembangan nilai, kebutuhan masyarakat, bakat dan minat peseta didik, peluang tenaga kerja, dan menyesuaikan dengan perkembangan ilmu pengetahuan dan tehnologi. Dalam merencanakan kurikulum, yang utama dirancang adalah tujuan yang hendak dicapai sesuai untuk berbagai pihak, isi kurikulum untuk mendukung pencapaian tujuan, strategi dalam mengembangkan kurikulum, dan evaluasi sebagai alat mengukur ketuntasan belajar dan ketercapaian tujuan.
\end{abstract}

\begin{abstract}
Abtract
Basic Islamic education curriculum is the Qur'an and Hadith, but not explained in detail. In the Qur'an and Hadith The term curriculum is more directed at the points of material that will be taught to students. PAI curriculum orientation refers to the development of values, community needs, talents and interests of students, opportunities for workers, and adjustments to the development of science and technology. In planning the curriculum, the main ones are the goals to be achieved according to various parties, curriculum content to support the achievement of goals, strategies in developing the curriculum, and evaluation as a tool to measure learning completeness and achievement of goals.
\end{abstract}

Kata Kunci: Kurikulum, Pendidikan Agama Islam, dan Sekolah Pendahuluan 


\section{Rahmad Nauli Siregar}

Kurikulum adalah sesuatu hal yang paling penting dalam pendidikan. Kurikulum tidak ada habisnya diperbincangkan dan dipermasalahkan dalam dunia pendidikan. Hal itu dikarenakan kurikulum mempunyai peranan yang sangat penting untuk acuan terhadap tujuan pembelajaran yang akan dicapai.

Demikian juga halnya kurikulum PAl tidak kalah penting dengan kurikulum mata pelajaran lainnya, karena kurikulum PAI memuat kebutuhan Duniawi dan akhirat. Oleh karena itu kurikulum PAl harus dikembangkan sesuai dengan dasar/landasan yang jelas dan sesuai dengan pedoman ummat Islam Al-qur'an dan Hadist. Kemudian menyesuaikan dengan filosof negara yakni pancasila dan UUD.

Penyusunan kurikulum PAI mengaitkan beberapa komponen yang saling berkaitan, awalnya menentukan Tujuan yang akan dicapai, beranjak dari tujuan kemudian isi kurikulum/bahan ajar yang relevan untuk menunjang pencapaian tujuan, strategi yang efektif, dan evaluasi sebagai tolak ukur keberhasilan.

Tujuan penulisan jurnal ini adalah agar mengetahui tentang pengembangan kurikulum PAl, serta mengetahui Dasar Pengembangan Kurikulum PAI, Komponen Kurikulum, dan Orientasi Pengembangan Kurikulum PAI.

\section{Dasar Pengembangan Kurikulum PAI}

Penting sekali untuk mengetahui yang menjadi dasar dalam pengembangan kurikilum PAI selain itu, dasar ini juga yang melatar belakangi pentingnya kurikulum PAI tersebut dikembangkan pada dunia pendidikan di Indonesia. Dasar pengembangan kurikulum PAI adalah sebagai berikut:

\section{Dasar Al-Qur'an}

Kurikulum dalam pendidikan Islam, dikenal dengan manhaj yang bermakna jalan yang terang, atau jalan terang yang dilalui oleh manusia pada berbagai bidang kehidupannya. ${ }^{1}$ Kurikulum pendidikan Islam

1Omar Muhammad Al-Toumy Al-Syaibany, Falsafah Pendidikan Islam (Jakart: Bulan Bintang, Terjemahan Hasan Langgulung, 1979), hal 478 
bersumber dari tujuan pendidikan Islam, yaitu tujuan penciptaan manusia sebagai Abdullah dan khalifah di Bumi.2

Menurut Abdullah Idi yang dikutip dari pendapat Arifin bahwa tujuan pendidikan Islam merealisasikan manusia muslim yang beriman, bertakwa dan berilmu pengetahuan yang mampu mengabdikan dirinya kepada sang Khalik dengan sikap dan kepribadian bulat yang menyerahkan diri kepadaNya dalam segala aspek kehidupannya dalam rangka mencari keridhoannya. $^{3}$

Di dalam ajaran Islam, baik Al-Qur'an, al-sunnah maupun pendapat para pakar pendidikan agama Islam tidak dijumpai pengertian kurikulum sebagaimana yang dikembangkan oleh pakar pendidikan modern. Kurikulum dalam pandangan Islam lebih diartikan sebagai susunan mata pelajaran yang harus diajarkan kepada peserta didik. ${ }^{4}$

Sumber bahan dan materi kurikulum pendidikan Islam dapat dikembangkan melalui bahan yang terdapat dalam nash dan realitas kehidupan. Kutipan beberapa nash Al-Qur'an dan Hadist berikut dapat memberikan gambaran sumber bahan kurikulum pendidikan Islam atau menjadi isi dari suatu kegiatan pendidikan Islam. ${ }^{5}$ Sebagaimana di jelaskan pada suroh Luqman ayat 12 dengan bunyi:

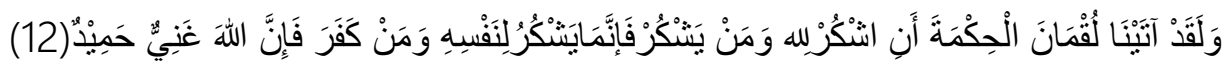
Dan sesungguhnya telah Kami berikan hikmah kepada Lukman, yaitu: "Bersyukurlah kepada Allah. Dan barang siapa yang bersyukur (kepada Allah), maka sesungguhnya ia bersyukur untuk dirinya sendiri; dan barang siapa yang tidak bersyukur, maka sesungguhnya Allah Maha Kaya lagi Maha Terpuji".

Tafsir ayat ini adalah: bahwa Allah Subhaanahu wa Ta'aala memberitahukan tentang nikmat-Nya yang diberikan kepada hamba-Nya

${ }^{2}$ Abdullah Idi, Pengembangan Kurikulum: Teori dan Praktek (Jakarta: Gaya Media Pratama, 1999), hal 16

${ }^{3} / \mathrm{bid}$

${ }^{4}$ Abuddin Nata, Kapita Selekta Pendidikan Islam : Isu-isu kontemporer tentang Pendidikan Islam (Jakarta: Rajawali Pers, 2013), hal 123

${ }^{5}$ Abdullah Idi, Pengembangan Kurikulum...hal 18 


\section{Rahmad Nauli Siregar}

yang mulia; Luqman. Nikmat yang diberikan-Nya itu adalah hikmah (kebijaksanaan), yaitu pengetahuan terhadap kebenaran sesuai keadaan yang sebenarnya dan mengetahui rahasianya. Hikmah adalah mengetahui hukum-hukum dan mengetahui rahasia yang terkandung di dalamnya, karena terkadang seseorang berilmu namun tidak mengetahui hikmahnya. Berbeda dengan hikmah, maka ia mencakup ilmu, amal, dan hikmah atau rahasianya.

Demikian pula memberitahukan, bahwa syukur yang dilakukan seseorang manfaatnya untuk dirinya sendiri, dan jika kufur, maka bencananya pun untuk dirinya sendiri. ${ }^{6}$

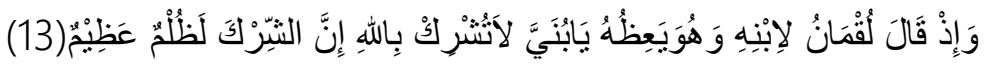
Dan (ingatlah) ketika Lukman berkata kepada anaknya, di waktu ia memberi pelajaran kepadanya: "Hai anakku, janganlah kamu mempersekutukan (Allah) sesungguhnya mempersekutukan (Allah) adalah benar-benar kelaliman yang besar".

Tafsir Ayat ini adalah :

Oleh karena kebijaksanaannya, maka dalam nasehatnya ia sebutkan perintah dan larangan disertai dengan targhib dan tarhib (dorongan dan ancaman). Dia memerintahkan anaknya berbuat ikhlas dan melarangnya berbuat syirk serta menerangkan sebab mengapa dilarang, yaitu karena syirk adalah kezaliman yang besar.

Arti zalim adalah menempatkan sesuatu yang bukan pada tempatnya, karena dalam syrik seseorang menempatkan ibadah kepada yang bukan tempatnya, seperti kepada patung, berhala dan makhluk-makhluk lainnya. Padahal yang seharusnya disembah adalah yang menciptakan alam semesta, yang memberinya rezeki dan yang menguasainya.

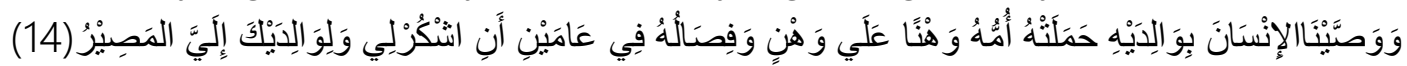
Dan Kami perintahkan kepada manusia (berbuat baik) kepada dua orang ibu-bapaknya; ibunya telah mengandungnya dalam keadaan lemah yang bertambah-tambah, dan menyapihnya dalam dua tahun.Bersyukurlah

${ }^{6}$ Abu Yahya Marwan bin Musa, Tafsir al-Qur'an Hidayatul Insan, Jilid 3, hal 288 di www.tafsir.co.id 
kepada-Ku dan kepada dua orang ibu bapakmu, hanya kepada-Kulah kembalimu.

Di ayat ini, Allah menggambarkan kesusahan seorang ibu dalam merawat anaknya, mengapa hanya jasa ibu yang digambarkan dengan sedemikian lemahnya. Karena peranan ibu lebih berat dari ayah, mulai dari proses mengandung, hingga melahirkan dan menyapihnya. Kata Wahnan berarti kelemahan atau kerapuhan. Yang dimaksud disini adalah ibu sangat lemah saat mengandung hingga diibaratkan kelemahan itu sendiri. ${ }^{7}$

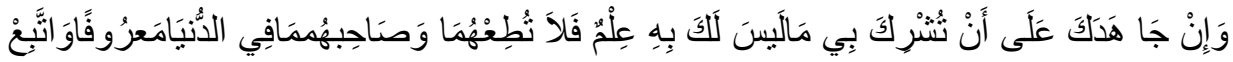

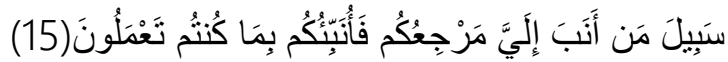

"Dan jika keduanya memaksa kamu untuk mempersekutukan Aku dengan sesuatu yang tidak ada pengetahuanmu tentang itu, maka jangan lah engkau mematuhi keduanya, dan pergaulilah keduanya di dunia dengan baik, dan ikutilah jalan orang yang kembali kepada-Ku, kemudian hanya kepada-Kaulah kembali kamu, maka Ku-beritakan kepada kamu apa yang telah kamu kerjakan." ${ }^{8}$

Ayat ini sekaligus memberitahu bahwa mempergauli keduanya dengan baik hanya dalam urusan dunia, bukan keagamaan. Seperti nabi Ibrahim, dia tetap berlaku santun pada bapaknya sekalipun pembuat berhala, namun nabi Ibrahim tidak sependapat dengan hal aqidah. ${ }^{9}$

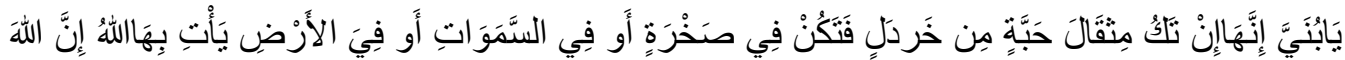

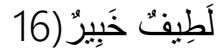

"Wahai anakku, sesungguhnya jika ada seberat biji sawi, dan berada dalam batukarang atau dilangit atau di dalam bumi, niscaya Allah akan mendatangkannya, Sesungguhnya Allah Maha Halus lagi Maha Mengetahui."

Dalam ayat ini terdapat kata Latif, yang artinya lembut, halus, atau kecil. Dari makna ini lahirlah makna ketersembunyian dan ketelitian. Imam Ghazali menjelaskan bahwa yang berhak menyandang sifat ini hanyalah

\footnotetext{
${ }^{7}$ Abu Yahya Marwan bin Musa, Tafsir al-Qur'an Hidayatul Insan...hal 289

${ }^{8}$ Departemen Agama, A/-Qur'an dan Terjemahnya (Bandung: PT Syma Examedia Arkanleem), hal 412

${ }^{9}$ Abu Yahya Marwan bin Musa, Tafsir al-Qur'an Hidayatul Insan...hal 289
} 


\section{Rahmad Nauli Siregar}

yang mengetahui perincian kemashlahatan dan seluk beluk rahasianya. Yang kecil dan halus, kemudian menempuh jalan untuk menyampaikannya dengan lembut dan bukan kekerasan. Yaitu Allah, karena dia selalu menghendaki kemaslahatan untuk makhluknya. Ayat ini menggambarkan kekuasaan Allah dalam menghitung amal manusia betapapun sedikitnya. ${ }^{10}$

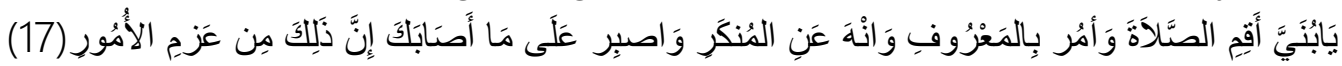
"Wahai anakku, laksanakanlah shalat dan perintahkanlah mengerjakan yang ma'ruf dan cegahlah dari kemunkaran dan bersabarlah terhadap apa yang menimpamu. Sesungguhnya yang demikian itu termasuk hal-hal diutamakan. "n1

Ayat ini menjelaskan tentang amal ma'ruf nahi munkar, yang puncaknya pangkalnya adalah shalat, serta amal kebaikan yang tercermin adalah buah dari shalat yang dilaksanakan dengan benar. Kata 'azm dari segi bahasa berarti kekuatan hati atau tekad. ${ }^{12}$

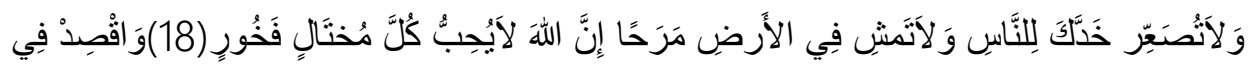

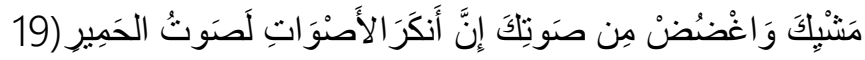

Artinya : "Dan janganlah kamu memalingkan wajah dari manusia (karena sombong) dan janganlah berjalan dibumi dengan akuh. Sungguh, Allah tidak menyukai orang-orang yang sombong dan membanggakan diri". 13 Artinya : "Dan sederhanakanlah dalam berjalan dan lunakkanlah suaramu, Sesungguhnya seburuk-buruk suara ialah suara keledai".

Ayat ini menerangkan nasihat Luqman dalam berperilaku terhadap manusia. Materi aqidah yang disampaikan selalu berbarengan dengan akhlaq agar tidak menimbulkan kebosanan, ayat ini melarang manusia untuk sombong dan angkuh kepada orang lain.

Kata tusha'ir terambil dari kata ash-sha'ar, yaitu penyakit yang menimpa unta sehingga lehernya sulit menengok karena keseleo, orang yang sulit memalingkan wajah pada orang lain karena sombong, diumpamakan seperti leher unta yang keseleo, susah digerakkan karena

\footnotetext{
${ }^{10}$ Abu Yahya Marwan bin Musa, Tafsir al-Qur'an Hidayatul Insan...hal 290

${ }^{11}$ Departemen Agama RI, Al-Qur'an dan Terjemahnya... hal 412

${ }^{12}$ Abu Yahya Marwan bin Musa, Tafsir al-Qur'an Hidayatul Insan...hal 290

${ }^{13}$ Departemen Agama RI, Al-Qur'an dan Terjemahnya....hal 412
} 
sombong. Kata al-ardh, artinya tanah, mengiisyaratkan manusia untuk tidak sombong, karena berasal dari tanah dan tak ada yang patut disombongkan. ${ }^{14}$

Tafsir surah Al-Luqman ayat 12-19 merupakan inti dari kurikulum pendidikan islam. Kurikulum pendidikan islam merupakan satu komponen pendidikan agama berupa alat untuk mencapai tujuan.

Syarat kurikulum pendidikan islam adalah :

1. Akidah

2. Syariah

3. Muamalah

Dapat dipahami bahwa orientasi pendidikan Islam, memiliki keterkaitan dengan pemahaman akan fungsi keberadaan manusia dimuka bumi, yakni sebagai khalifah. Agar fungsi kekhalifaan ini bisa berjalan dengan sempurna, maka peran ilmu pengetahuan sangat diperlukan guna menjaga hubungan manusia dengan Khaliknya, Manusia dengan manusia, manusia dengan Alam. ${ }^{15}$ Kurikulum Pendidikan Islam adalah kurikulum yang dilandasi asas-asas kebenaran wahyu, yang sumbernya berasal dari AlQur'an dan As-sunnah

\section{Dasar Hadist}

Seperti halnya dalam hadist juga tidak terdapat mengenai pengertian kurikulum lebih detail, akan tetapi dalam hadist dijelaskan bahwa hadist tersebut merupakan hadist pendidikan sekaligus inti dari kurikulum PAI sebagaimana dalam hadist:

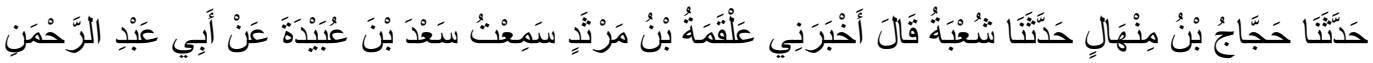

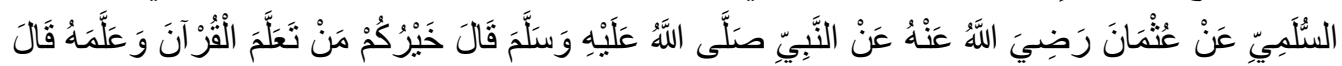

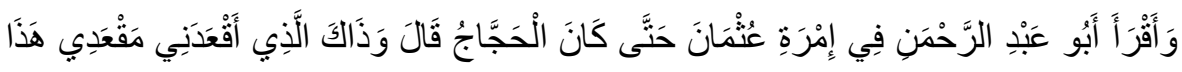
Artinya: Telah menceritakan kepada kami hujjaj ibn Minhaal telah menceritakan syu'bah ia berkata 'Alqamah ibn mursyid telah mengkhabarkan kepadaku saya mendengar Said ibn 'Ubaidah dari ayah Abdurrahman al-silmy dari 'Usman ra Nabi SAW telah bersabda: "Yang

\footnotetext{
${ }^{14}$ Abu Yahya Marwan bin Musa, Tafsir al-Qur'an Hidayatul Insan.hal 291

15 Ibid, hal 18
} 
Rahmad Nauli Siregar

paling baik di antara kamu adalah orang yang mempelajari Al-Quran dan mengajarkannya. ${ }^{16}$

Menurut Hadist diatas bahwa Al-Qur'an adalah pedoman utama dalam pendidikan Islam sekaligus kurikulum pendidikan Islam yang harus dipelajari dan diamalkan. Karna didalam Al-qur'an telah dijelaskan ilmu akhirat dan ilmu duniawi. Maka jelas bahwa pendidikan Islam harus berdasarkan pada Al-Qur'an dan Hadist.

\section{Pendapat para Pakar Pendidikan}

Secara terminologis, para ahli telah banyak mendefenisikan kurikulum di antaranya.

1. Menurut Al-Rasyidin kurikulum dalam persfektif falsafah pendidikan islami adalah alat atau instrument untuk mendidikkan peserta didik dalam mengembangkan potensi jismiyyah dan ruhaniyyah agar mereka kelak mampu mengenali kembali dan meneguhkan syahadah primordialnya itu adalah Allah Swt. Aktualisasi konkrit dari syahadah adalah kemampuan mereka dalam menjalankan fungsi sebagai 'abd Allah dan tugasnya sebagai khalifah Allah di muka bumi. ${ }^{17}$

2. Muhaimin menegaskan dalam Diktat Neliwati bahwa pengembangan kurikulum Pendidikan Agama Islam adalah sebagai kegiatan menghasilkan kurikulum PAl, proses yang mengaitkan satu komponen dengan komponen lainnya untuk menghasilkan kurikulum PAl yang lebih baik, atau kegiatan penyusunan, pelaksanaan, penilaian, dan penyempurnaan kurikulum PAI. ${ }^{18}$

${ }^{16}$ Hadis - Hadis Tentang Kurikulum Pendidikan _ fathimah.htm//Muhammad bin Ismail Abu Abdillah al-Bukhari, al-Jami' as-Shahih al-Mukhtashar, juz. 4 Beirut: Dar Ibn Katsir, 1987

${ }^{17}$ Al-Rasyidin, Falsafah Pendidikan Islam (Medan: Perdana Mulya Sarana, 2008), hal162

${ }^{18}$ Neliwati, Diktat Pengembangan Kurikulum PA/ (Medan: 2013) hal 9 
3. Zakiah Daradjat berpendapat bahwa kurikulum sebagai suatu program yang direncanakan dalam bidang pendidikan dan dilaksanakan untuk mencapai sejumlah tujuan pendidikan tertentu. ${ }^{19}$

4. Addamardasyi Sarhan dan Munir Kamil, sebagaimana dikutip alSyaibani mengatakan bahwa kurikulum adalah sejumlah pengalaman pendidikan, kebudayaan, sosial, olah raga dan kesenian yang disediakan oleh sekolah bagi murid-muridnya di dalam dan di luar sekolah dengan maksud menolong untuk berkembang menyeluruh dalam segala segi dan merubah tingkah laku mereka sesuai dengan tujuan pendidikan. ${ }^{20}$

5. S. Nasution menyatakan ada beberapa penafsiran lain tentang kurikulum. Diantaranya; pertama, kurikulum sebagai produk (sebagai hasil pengembangan kurikulum), kedua, kurikulum sebagai program (alat yang dilakukan sekolah untuk mencapai tujuan), ketiga,kurikulum sebagai hal-hal yang diharapkan akan dipelajari oleh siswa (sikap, keterampilan tertentu), dan keempat, kurikulum dipandang sebagai pengalaman siswa. ${ }^{21}$

\section{Undang-Undang}

Undang-Undang Republik Indonesia Nomor 20 Tahun 2003 Tentang Sistem Pendidikan Nasional Bagian Kesembilan tentang Pendidikan Keagamaan Pasal 30:

1) Pendidikan keagamaan diselenggarakan oleh Pemerintah dan/atau kelompok masyarakat dari pemeluk agama, sesuai dengan peraturan perundang-undangan.

2) Pendidikan keagamaan berfungsi mempersiapkan peserta didik menjadi anggota masyarakat yang memahami dan mengamalkan nilai-nilai ajaran agamanya dan/atau menjadi ahli ilmu agama.

${ }^{19}$ Zakiah Daradjat, IImu Pendidikan Islam (Jakarta: Bumi Aksara, 1992), hal 121

${ }^{20}$ Omar Muhammad al-Toumy al-Syaibani, Falsafah Pendidikan Islam, terj. Hasan Langgulung (Jakarta: Bulan Bintang, 1979), hal 485

${ }^{21}$ S. Nasution, Asas-asas Kurikulum (Jakarta: Bumi Aksara, 1994), hal 5-9 


\section{Rahmad Nauli Siregar}

3) Pendidikan keagamaan dapat diselenggarakan pada jalur pendidikan formal, nonformal, dan informal.

4) Pendidikan keagamaan berbentuk pendidikan diniyah, pesantren, pasraman, pabhaja samanera, dan bentuk lain yang sejenis.

5) Ketentuan mengenai pendidikan keagamaan sebagaimana dimaksud pada ayat (1), ayat (2), ayat (3), dan ayat (4) diatur lebih lanjut dengan peraturan pemerintah.

Kemudian Bab X Tentang Kurikulm Pasal 36: 22

1. Pengembangan kurikulum dilakukan dengan mengacu pada standar nasional pendidikan untuk mewujudkan tujuan pendidikan nasional.

2. Kurikulum pada semua jenjang dan jenis pendidikan dikembangkan dengan prinsip diversifikasi sesuai dengan satuan pendidikan, potensi daerah, dan peserta didik.

3. Kurikulum disusun sesuai dengan jenjang pendidikan dalam kerangka Negara Kesatuan Republik Indonesia dengan memperhatikan:
a. peningkatan iman dan takwa;
b. peningkatan akhlak mulia;
c. peningkatan potensi, kecerdasan, dan minat peserta didik;
d. keragaman potensi daerah dan lingkungan;
e. tuntutan pembangunan daerah dan nasional;
f. tuntutan dunia kerja;
g. perkembangan ilmu pengetahuan, teknologi, dan seni;
h. agama;
i. dinamika perkembangan global; dan
j. persatuan nasional dan nilai-nilai kebangsaan.

4. Ketentuan mengenai pengembangan kurikulum sebagaimana dimaksud pada ayat, ayat (2), dan ayat (3) diatur lebih lanjut dengan peraturan pemerintah.

\section{Pasal 37}

1. Kurikulum pendidikan dasar dan menengah wajib memuat:

a. pendidikan agama;

22 Depertemen pendidikan nasional (Undang-undang NO. 20 TH.2003 Tentang Sistem Pendidikan Nasional) 
b. pendidikan kewarganegaraan;

c. bahasa;

d. matematika;

e. ilmu pengetahuan alam;

f. ilmu pengetahuan sosial;

g. seni dan budaya;

h. pendidikan jasmani dan olahraga;

i. keterampilan/kejuruan; dan

j. muatan lokal.

2. Kurikulum pendidikan tinggi wajib memuat:
a. pendidikan agama;
b. pendidikan kewarganegaraan; dan
c. bahasa.

3. Ketentuan mengenai kurikulum sebagaimana dimaksud pada ayat (1) dan ayat diatur lebih lanjut dengan peraturan pemerintah. ${ }^{23}$

\section{Pasal 38: 24}

1) Kerangka dasar dan struktur kurikulum pendidikan dasar dan menengah ditetapkan oleh Pemerintah.

2) Kurikulum pendidikan dasar dan menengah dikembangkan sesuai dengan relevansinya oleh setiap kelompok atau satuan pendidikan dan komite sekolah/madrasah di bawah koordinasi dan supervisi dinas pendidikan atau kantor departemen agama kabupaten/kota untuk pendidikan dasar dan provinsi untuk pendidikan menengah.

3) Kurikulum pendidikan tinggi dikembangkan oleh perguruan tinggi yang bersangkutan dengan mengacu pada standar nasional pendidikan untuk setiap program studi.

4) Kerangka dasar dan struktur kurikulum pendidikan tinggi dikembangkan oleh perguruan tinggi yang bersangkutan dengan mengacu pada standar nasional pendidikan untuk setiap program studi.

23 Depertemen pendidikan nasional (Undang-undang NO. 20 TH.2003 Tentang Sistem Pendidikan Nasional)

${ }^{24}$ Depertemen pendidikan nasional (Undang-Undang No. 20 Tahun. 2003 Tentang Sistem Pendidikan Nasional) 


\section{Rahmad Nauli Siregar}

\section{Peraturan Pemerintah}

Peraturan Menteri Pendidikan dan Kebudayaan RI (Permendikbud) Nomor 160 Tahun 2014 tentang Pemberlakuan Kurikulum Tahun 2006 dan Kurikulum 2013 bersama ini disampaikan beberapa pertimbangan sebagai berikut :

1. Berdasarkan Pasal 3 ayat 2 Peraturan Pemerintah (PP) Nomor 55 Tahun 2007 tentang Pendidikan Agama dan Keagamaan disebutkan bahwa Pengelolaan Pendidikan Agama dilaksanakan oleh Menteri Agama.

2. Pendidikan Agama Islam tidak termasuk kelompok mata pelajaran (mapel) ujian nasional, tetapi kelompok ujian sekolah, sehingga penyelenggaraan dan penilaian mapel Pendidikan Agama Islam tergantung pada kebijakan satuan pendidikan masing-masing. ${ }^{25}$

\section{Komponen Kurikulum}

Komponen adalah bagian yang integral dan fungsional yang tidak terpisahkan dari suatu system pendidikan kurikulum karena komponen itu sendiri mempunyai peranan dalam pembentukan system kurikulum. Sebagai sebuah system, kurikulum mempunyai komponen-komponen. Seperti halnya dalam system manapun, kurikulum harus mempunyai komponen lengkap dan fungsional baru bisa dikatakan baik. ${ }^{26}$

Dalam menyusun kurikulum yang baik yang paling utama diperhatikan adalah komponen tujuan, setelah mengetahui tujuan apa yang hendak dicapai maka selanjutnya menetapkan bahan ajar/materi kurikulum yang sesuai dengan tujuan pembelajaran, kemudian materi disesuaikan dengan strategi yang tepat sehingga isi dari materi tersampaikan kepada peserta didik, dan setelah itu komponen evaluasi sebagai alat untuk mengukur tingkat kemampuan peserta didik dalam menguasai materi ataupun sebagai alat untuk mengetahui apakah tujuan pembelajaran telah

25 Peraturan Menteri Pendidikan dan Kebudayaan RI (Permendikbud) Nomor 160 Tahun 2014

26 Lias Hasibuan, Kurikulum dan Pemikiran Pendidikan (Jakarta: Gaung Parsada, 2010), hal 37 
berhasil. Dan untuk membahas komponen-komponen kurikulum akan dijelaskan sebagai berikut:

\section{Tujuan}

Kurikulum hakikatnya adalah alat untuk mencapai tujuan pendidikan, maka tujuan kurikulum sebenarnya adalah tujuan dari setiap program pendidikan yang akan ditanamkan pada diri peserta didik. ${ }^{27}$ Komponen tujuan adalah komponen kurikulum yang menjadi target atau sasaran yang mesti dicapai dari melaksanakan suatu kurikulum. Komponen ini sangat penting karena melalui tujuan, materi proses dan evaluasi dapat dikendalikan untuk kepentingan mencapai tujuan kurikulum dimaksud. Tujuan kurikulum dapat dispesifikasikan ke dalam tujuan pembelajaran umum yaitu berupa tujuan yang dicapai untuk satu semester, atau tujuan pembelajaran khusus yang menjadi target pada setiap kali tatap muka. ${ }^{28}$

Penjenjangan tujuan pendidikan dirumuskan dengan hierarki:
a. Tujuan Pendidikan Nasional
b. Kompetensi Lintas Kurikulum
c. Kompetensi Tamatan
d. Kompetensi Rumpun Mata Pelajaran
e. Kompetensi Mata Pelajaran
f. Indicator Hasil Belajar. ${ }^{29}$

Menurut Ali Mudlofir Tujuan pendidikan Nasional digali dari falsafah bangsa Pancasila, dan dituangkan dalam UU SISDIKNAS 2003 Pasal 3: " Pendidikan Nasional berfungsi mengembangkan kemampuan dan membentuk watak serta peradaban bangsa yang bermartabat dalam rangka mencerdaskan kehidupan bangsa, bertujuan untuk berkembangnya potensi peserta didik agar menjadi manusia yang beriman dan bertakwa kepada Tuhan Yang Maha Esa, berakhlak mulia, berilmu, cakap, kreatif,

${ }^{27}$ Ali Mudlofir, Aplikasi Pengembangan Kurikulum Tingkat Satuan Pendidikan dan Bahan Ajar dalam Pendidikan Agama Islam (Jakarta: PT Rajagrafindo Persada, 2012), hal 7

28 Lias Hasibuan, Kurikulum dan Pemikiran Pendidikan... hal 38

29 Ali Mudlofir, Aplikasi Pengembangan Kurikulum Tingkat Satuan Pendidikan... hal 8 


\section{Rahmad Nauli Siregar}

mandiri, dan menjadi warga negara yang demokratis serta bertanggung jawab." 30

Dalam menentukan dan merumuskan tujuan kurikulum ada empat sumber yang dapat dijadikan landasan yaitu:

a. Tujuan Pendidikan Islam, yaitu harus sesuai dengan tujuan Penciptaan manusia, yaitu Sebagai Hamba Allah yang mengabdi kepadaNya dan sebagai Khalifah dimuka Bumi, sebagaimana Firman Allah :

b. Falsafah bangsa, rumusan tujuan kurikulum harus mencerminkan dan mengandung nilai-nilai yang terdapat dalam pancasila. Nilai-nilai tersebut harus menjiwai dalam setiap jenjang rumusan kurikulum, mulai tingkat kelembagaan, tingkat mata pelajaran, dan tingkat pembelajaran.

c. Strategi pembangunan, yakni penanaman sumber daya manusia Indonesia seutuhnya untuk mewujudkan masyarakat adil dan makmur, materiil dan spiritual. Makna dan hakikat tersebut harus tercermin dalam tujuan kurikulum sehingga dapat menghasilkan sumber daya manusia yang memiliki potensi untuk melaksanakan pembangunan.

d. Hakikat anak didik, yakni bahwa tujuan pendidikan dan tujuan pendidikan pada dasarnya untuk kepentingan anak didik, maka dalam merumuskan tujuan dan isi kurikulum haruslah memerhatikan kepentingan anak didik. Kemampuan, minat dan perhatian, sikap dan perilaku serta cirri kepribadian anak didik merupakan dimensidimensi penting untuk diperhatikan dalam merumuskan kurikulum.

e. Ilmu pengetahuan dan teknologi, maksudnya dalam merumuskan tujuan pendidikan haruslah memperhatikan perkembangan IPTEK dengan penemuan IPTEK. Sinergi keempat sumber tersebut tentu akan menghasilkan tujuan pendidikan yang lebih baik dalam arti akan dapat mewujudkan manusia Indonesia yang memiliki pengetahuan, kemampuan, dan kepribadian secara terpadu. ${ }^{31}$
30 Ibid hal 8
${ }^{31}$ Ibid hal 8-9 
Kemudian dalam kegiatan belajar mengajar di dalam kelas, tujuantujuan khusus lebih diutamakan, karena lebih jelas dan mudah pencapaiannya. Dalam mempersiapkan pelajaran guru menjabarkan tujuan mengajarnya dalam bentuk tujuan-tujuan khusus yang bersifat operasional. Bloom mengemukakan sebagaimana yang dikutip Nana Syaodih ada tiga kategori tujuan mengajar sesuai dengan domain-domain perilaku individu, yaitu kognitif, afektif, dan psikomotorik. Domain kognitif berkenaan dengan kemampuan intelektual atau berfikir. Domain afektif berkenaan dengan penguasaan dan pengembangan perasaan, sikap, minat dan nilai-nilai. Domain psikomotorik menyangkut penguasaan dan pengembangan keterampilan-keterampilan motorik. ${ }^{32}$

\section{Bahan Ajar}

Isi suatu program kurikulum di sekolah dibedakan berdasarkan jenis bidang studi yang disajikan dan program masing-masing bidang studi tertentu. ${ }^{33}$ Bahan ajar merupakan materi kurikulum ataupun isi kurikulum. Dalam UU Pendidikan tentang system Pendidikan Nasional ditetapkan bahwa isi kurikulum merupakan bahan kajian dan pelajaran untuk mencapai tujuan penyelenggaraan satuan pendidikan yang bersangkutan dalam rangka upaya pencapaian tujuan pendidikan nasional (Bab IX, Pasal 39).

Kurikulum Pendidikan Islam harus sesuai dengan Tujuan pendidikan itu sendiri yaitu menjadikan menusia sebagai khalifah dan abd sebagaimana yang dijelaskan dalam suroh Luqman diatas, bahwa materi yang harus dicantumkan dalam kurikulum Pendidikan Agama Islam harus menyangkut kepada Aqidah, Syariah, dan Muamalah.

Sesuai dengan rumusan tersebut, isi kurikulum dikembangkan dan disussun berdasarkan prinsip-prinsip sebagai berikut:

a. Materi kurikulum berupa bahan pembelajaran yang terdiri dari bahan kajian topic-topik pelajaran tentang informasi ilmu pengetahuan yang dikaji oleh siswa dalam proses pembelajaran.

32 Nana Syaodih, Pengembangan Kurikulum Teori dan Praktek (Bandung: PT Remaja Rosdakarya, 2011), Hal 103-104

${ }^{33}$ Hafni Ladjid, Pengembangan Kurikulum Menuju Kurikulum Berbasis Kompetensi (Ciputat: PT Ciputat Press Group, 2005), hal 5 
b. Materi kurikulum mengacu pada pencapaian tujuan pembelajaran bidang studi tertentu. Perbedaan ruang lingkup dan urutan bahan pelajaran disebabkan oleh perbedaan tujuan dari masing-masing mata pelajaran dan tingkat satuan pendidikan.

c. Materi kurikulum diarahkan untuk mencapai tujuan pembelajaran mata pelajaran dan pendidikan Nasional. Dalam hal ini tujuan pendidikan Nasional merupakan target tertinggi yang hendak dicapai melalui penyampaian materi kurikulum. ${ }^{34}$

Menurut Asfiati ${ }^{35}$ ada beberapa criteria yang bisa digunakan dalam merancang isi kurikulum:

a. Isi kurikulum harus sesuai, tepat dan bermakna bagi perkembangan sisiwa, artinya sejalan dengan tahap perkembangan.

b. Isi kurikulum harus mencerminkan kenyataan sosial, artinya sesuai dengan tuntutan hidup nyata dalam masyarakat.

c. Isi kurikulum dapat mencapai tujuan yang komprehensif, artinya mengandung aspek intelektual, moral, sosial, dan skillsecara integral.

d. Isi kurikulum harus berisikan bahan pelajaran yang jelas, teori, prinsip, bukan hanya sekedar informasi yang teorinya masih samar-samar.

e. Isi kurkulum harus dapat menunjang tercapainya tujuan pendidikan, ini dikarenakan isi kurikulum berupa program pembelajaran yang dilaksanakan oleh guru dalam menghantarkan anak didik mencapai tujuan pendidikan.

\section{Strategi Pembelajaran}

Penyusunan sekuens bahan ajar berhubungan erat dengan strategi atau metode mengajar. Pada waktu guru menyusun sekuens suatu bahan ajar, ia juga harus memikirkan strategi mengajar mana yang sesuai untuk menyajikan bahan ajar dengan urutan seperti itu. Strategi meliputi rencana,

${ }^{34}$ Siti Halimah, Telaah Kurikulum (Medan: Perdana Pubilhising, 2010), hal 147-147

${ }^{35}$ Asfiati, Manajemen Pembelajaran Pendidikan Agama Islam:Berorientasi pada Pengembangan Kurikulum 2013 (Bandung: Citapustaka Media, 2014), hal 121-122 
metode, dan perangkat kegiatan yang direncanakan untuk mencapai tujuan tertentu. ${ }^{36}$

Strategi pembelajaran merupakan factor dan menempati posisi penting dalam kurikulum, karena tugas-tugas yang akan dikerjakan oleh siswa dan guru perlu dimuat. Proses perencanaan dan penyusunannya hendaklah didasarkan pada perilaku awal siswa. Dalam hubungan ini, ada tiga alternative pendekatan yang dapat digunakan, yaitu:

a. Pendekatan yang berpusat mata pelajaran, dimana materi pembelajaran terutama bersumber dari mata pelajaran. Penyampaiannya dilakukan melalui komunikasi tersebut dapat digunakan sebagai strategi mengajar.

b. Pendekatan yang berpusat pada siswa. Pembelajaran dilaksanakan berdasarkan kebutuhan, minat, dan kemampuan siswa. Dalam pendekatan ini lebih banyak digunakan strategi dalam rangka individualisasi pembelajaran. Seperti belajar mandiri, paket belajar dan sebagainya.

c. Pendekatan yang berorientasi pada kehidupan masyarakat. Pendekatan ini bertujuan mengintegralisasikan sekolah dan masyarakat dan untuk memperbaiki kehidupan masyarakat. Prosedur yang ditempuh ialah dengan mengundang masyarakat ke sekolah atau siswa berkunjung ke masyarakat. Metode yang digunakan terdiri dari: karyawisata, narasumber, kerja pengalaman, survey dll. ${ }^{37}$

\section{Evaluasi}

Evaluasi merupakan suatu komponen kurikulum, karena kurikulum adalah pedoman penyelenggara kegiatan pembelajaran. Dengan evaluasi dapat diperoleh informasi yang akurat tentang penyelenggaraan pembelajaraan dan keberhasilan belajar siswa. Berdasarkan informasi itu dapat dibuat keputusan tentang kurikulum itu sendiri, pembelajaran, kesulitan dan upaya bimbingan yang perlu dilakukan.

36 Tim Pengembang MKDP, Kurikulum dan Pembelajaran, (Jakarta: PT Raja Grafindo Persada, 2011), hal 53

${ }^{37}$ Siti Halimah, Telaah Kurikulum...hal 148 


\section{Rahmad Nauli Siregar}

Aspek-aspek yang perlu dinilai bertitik tolak dari aspek-aspek yang akan dicapai, baik tujuan kurikulum, tujuan pembelajaran, dan tujuan belajar siswa. Setiap aspek dinilai berpangkal pada kemampuan-kemampuan apa yang hendak dikembangkan, sedangkan tiap kemampuan itu mengandung unsur pengetahuan, keterampilanm dan sikap serta nilai. Penetapan aspek yang dinilai mengacu pada criteria keberhasilan yang ditentukan dalam kurikulum tersebut.

Adapun jenis evaluasi yang dilaksanakan tergantung pada tujuan diselenggarakannya penilaian tersebut. Misalnya penilaian formatif dimaksudkan untuk mengetahui kemajuan siswa dan dalam upaya melakukan perbaikan yang dibutuhkan. ${ }^{38}$ Dalam kurikulum pendidikan dasar dan menengah evaluasi formatif digunakan untuk menilai penguasaan siswa setelah selesai mempelajari satu pokok bahasan. Hasil evaluasi formatif ini digunakan untuk memperbaiki proses belajar mengajar dan membantu mengatasi kesulitan-kesulitan belajar siswa. ${ }^{39}$

Berbeda dengan penilaian sumatif yang bermaksud menilai kemajuan siswa setelah satu semester atau dalam periode tertentu, untuk mengetahui siswa secara menyeluruh. Evaluasi sumatif mempunyai fungsi yang lebih luas daripada evaluasi formatif. Dalam kurikulum pendidikan dasar dan menengah evaluasi sumatif dimaksudkan untuk menilai kemajuan belajar siswa kenaikan kelas, kelulusan ujian serta menilai efektifitas program secara menyeluruh.

Dengan demikian norma yang digunakan adalah norma kelompok, yang lebih bersifat relative. Kelompok ini dapat berupa kelompok kelas, sekolah, daerah, ataupun nasional. Dalam implementasi kurikulum atau pelaksanaan pengajaran, criteria referenced digunakana pada evaluasi formatif, sedangkan norm referenced digunakan pada evaluasi sumatif. ${ }^{40}$

Dalam program mengajar komponen-komponen yang dievaluasi meliputi :

\footnotetext{
38 Siti Halimah, Telaah Kurikulum...hal 151-152

${ }^{39}$ Nana Syaodih, Pengembangan Kurikulum Teori dan Praktek...hal 111

40 /bid hal 111-112
} 
a. Komponen tingkah laku, mencakup : kognitif, afektif, dan psikomotorik

b. Komponen mengajar, mencakup : isi, metode, organisasi fasilitas, dan biaya

c. Komponen populasi, mencakup: siswa, guru, administrator, spesialis pendidikan, keluarga, dan masyarakat

Dan untuk mengevaluasi komponen-komponen tersebut bukan hanya melalui tes tetapi juga melalui nontes seperti, observasi, studi dokumentar, analisis hasil pekerjaan, angket dan sebagainya. ${ }^{41}$

\section{Orientasi Pengembangan Kurikulum PAI}

Kurikulum pendidikan Islam berorientasi kepada: ${ }^{42}$

1. Orientasi Pengembangan Nilai, dalam pandangan Islam, nilai terbagi atas dua macam, yaitu nilai ilahiyah (nilai yang turun dari Allah SWT) dan nilai insaniyah (nilai yang tumbuh dan berkembang dari peradaban manusia sendiri). Kedua nilai tersebut selanjutnya membentuk normanorma atau kaidah kehidupan yang dianut oleh masyarakat yang mendukungnya. Tugas kurikulum selanjutnya adalah menciptakan situasi-situasi dan program tertentu untuk tercapainya pelestarian kedua nilai tersebut. Orientasi ini menfokuskan kurikulum sebagai alat untuk tercapainya.

2. Orientasi sosial demand, yaitu Orientasi kurikulum adalah bagaimana memberikan kontribusi positif dalam perkembangan sosial dan kebutuhan masyarakat, sehingga output di lembaga pendidikan mampu menjawab dan mengejawantahkan masalah-masalah yang dihadapi mayarakat.

3. Orientasi tenaga kerja, manusia sebagai makhluk biologis mempunyai unsur-unsur mekanisme jasmani yang membutuhkan kebutuhankebutuhan lahiriah, misalnya makan-minum, bertempat tinggal yang layak, dan kebutuhan biologis lainnya. Kebutuhan-kebutuhan tersebut

\footnotetext{
${ }^{41}$ Nana Syaodih, Pengembangan Kurikulum Teori dan Praktek...hal 112

42 Ramayulis, IImu Pendidikan Islam (Jakarta: Kalam Mulia, 2008) hal 166
} 


\section{Rahmad Nauli Siregar}

harus dipenuhi secara layak, dan salah satu diantara persiapan untuk mendapatkan pemenuhan kebutuhan yang layak melalui pendidikan. Dengan, pendidikan pengamalan dan pengetahuan seseorang bertambah dan dapat menentukan kualitas dan kuantitas kerja seseorang. Hal ini karena dunia kerja dewasa ini semakin banyak saingan, dan jumlah perkembangan penduduk jauh lebih pesat dari penyediaan lapangan kerja.

Sebagai konsekuensinya, kurikulum pendidikan diarahkan untuk memenuhi kebutuhan kerja. Hal ini ditujukan setelah keluar dari lembaga sekolah, peserta didik mempunyai kemampuan dan keterampilan yang professional, berproduktif dan kreatif, mampu mendayagunakan sumber daya alam, sumber daya diri, dan sumber daya situasi yang mempengaruhinya. ${ }^{43}$

4. Orientasi peserta didik; memberikan kompas pada kurikulum untuk memenuhi kebutuhan peserta didik yang disesuaikan dengan bakat, minat dan potensi yang dimiliki. Orientasi ini diarahkan kepada pembinaan tiga dimensi peserta didiknya : (1) Dimensi Kepribadian sebagai manusia, yaitu kemampuan untuk menjaga integritas antara sikap, tingkah laku, dan moralitas, (2) Dimensi produktivitas, yaitu yang menyangkut apa yang dihasilkan anak didik dalam jumlah yang lebih banyak kualitas yang lebih baik setelah ia menamatkan pendidikannya, (3) Dimensi kreativitas yaitu yang menyangkut kemampuan anak didik untuk berfikir dan berbuat, menciptakan sesuatu yang berguna bagi diri sendiri dan masyarakat. ${ }^{44}$

5. Orientasi perkembangan ilmu pengetahuan dan tehnologi, melihat kondisi saat ini kemajuan IPTEK menuntut kita untuk hidup secara mengglobal dan mengikuti arus Modren serta membuat dan mengaplikasikan kurikulum pendidikan yang selaras dengan IPTEK. Sehingga pendidikan Islam tetap berkembang dan tidak buta akan iptek. Dalam hal ini kita harus mampu memilih dan memilah iptek yang positif bagi dunia pendidikan Islam.

${ }^{43}$ Ramayulis, IImu Pendidikan Islam...., hal 168

${ }^{44}$ Ramayulis, IImu Pendidikan Islam...., hal 167 
Karna kemajuan suatu zaman ditandai oleh kemajuan ilmu pengetahuan dan teknologi serta produk-produk yang dihasilkannya. Hampir semua kehidupan dewasa ini tidak lepas dari keterlibatan IPTEK, mulai dari kehidupan yang paling sederhana sampai kehidupan dan peradaban yang paling tinggi dengan IPTEK, masalah yang lebih rumit menjadi lebih mudah, masalah yang tidak berguna menjadi lebih berguna, maslaah yang using dan kemudian dibumbui dengan produk IPTEK menjadi lebih menarik. ${ }^{45}$

\section{Penutup}

Beranjak dari pembahasan diatas maka Dasar Kurikulum pendidikan Islam adalah Al-Qur'an dan Hadist, akan tetapi secara detail mengenai pengertian kurikulum tidak dijelaskan secara jelas dalam Al-Qur'an dan Hadist. Dalam Al-Qur'an dan Hadist Istilah kurikulum lebih di arahkan pada pokok-pokok materi yang akan diajarkan pada peserta didik. Maka dalam Al-Qur'an dan Hadist inti poko ajaran Islam adalah Aqidah, Muamalah, dan Syari'at.

Pendidikan Islam juga harus berdasarkan pada Falsafah Negara yaitu UUD dan Peraturan Pemerintah dan dalam merencanakan isi kurikulum, yang utama di rancang adalah tujuan yang akan hendak dicapai dan sesuai untuk berbagai pihak yang bersangkutan, kemudian Isi kurikulum guna untuk menunjang pencapaian tujuan, setelah itu strategi dalam mengembangkan kurikulum dan yang terakhir adalah evaluasi sebagai alat mengukur ketuntasan belajar dan ketercapaian tujuan.

Orientasi kurikulum PAI mengacu pada pengembangan nilai, kebutuhan masyarakat, bakat dan minat peseta didik, peluang tenaga kerja, dan menyesuaikan dengan perkembangan ilmu pengetahuan dan tehnologi.

\section{Daftar Pustaka}

Al-Rasyidin, Falsafah Pendidikan Islam, Medan: Perdana Mulya Sarana. 2008.

45 Ibid hal 167 
Rahmad Nauli Siregar

Asfiati, Manajemen Pembelajaran Pendidikan Agama Islam:Berorientasi pada Pengembangan Kurikulum 2013, Bandung : Citapustaka Media. 2014.

Daradjat Zakiah, Ilmu Pendidikan Islam, Jakarta : Bumi Aksara. 1992.

Departemen Agama, A/-Qur'an dan Terjemahnya, Bandung: PT Syma Examedia Arkanleema

Depertemen Pendidikan Nasional (Undang-Undang No. 20 Tahun. 2003 Tentang Sistem Pendidikan Nasional)

Lias Hasibuan, Kurikulum dan Pemikiran Pendidikan, Jakarta: Gaung Parsada. 2010

Hamalik Oemar, Pengajaran Unit, Bandung: Alumni. 1982, hal 202

Halimah Siti, Telaah Kurikulum, Medan: Perdana Publhising. 2010

Idi Abdullah, Pengembangan Kurikulum: Teori dan Praktek, Jakarta: Gaya Media Pratama. 1999

Ladjid Hafni, Pengembangan Kurikulum Menuju Kurikulum Berbasis Kompetensi, Ciputat: PT Ciputat Press Group. 2005

Mudlofir Ali, Aplikasi Pengembangan Kurikulum Tingkat Satuan Pendidikan dan Bahan Ajar dalam Pendidikan Agama Islam, Jakarta: PT Rajagrafindo Persada. 2012

Nata Abuddin, Kapita Selekta Pendidikan Islam: Isu-isu Kontemporer tentang Pendidikan Islam, Jakarta: Rajawali Pers. 2013.

Neliwati, Diktat Pengembangan Kurikulum PA/, Medan: 2013

Omar Mohammad Al-Toumy Al-Syaibany, Falsafah Pendidikan Islam, Jakarta: Bulan Bintang: Terjemahan Hasan Langgulung. 1979.

Peraturan Menteri Pendidikan dan Kebudayaan RI (Permendikbud) Nomor 160 Tahun 2014

Ramayulis, IImu Pendidikan Islam, Jakarta: Kalam Mulia. 2008

Syaodih Nana, Pengembangan Kurikulum Teori dan Praktek, Bandung: PT Remaja Rosdakarya. 2011

S. Nasution, Asas-asas Kurikulum, Jakarta: Bumi Aksara. 1994

Tim Pengembang MKDP, Kurikulum dan Pembelajaran, Jakarta: PT Raja Grafindo Persada. 2011 
Jihad-ilmiah.blogspot.com/kurikulum-pendidikan-islam.html. diakses pada tgl 06 Oktober 2015

Abu Yahya Marwan bin Musa, Tafsir al-Qur'an Hidayatul Insan, Jilid 3, hal 288 di www.tafsir.co.id 